\title{
Tradisi sebagai Wadah Ketahanan Budaya: Sebuah Kritik terhadap Kapitalisme dan Budaya Pasar
}

\author{
SYUHENDRI \\ Program Studi Penciptaan Teater, Program Pasca Sarjana, \\ Institut Seni Indonesia Yogyakarta.
}

\begin{abstract}
Tradition as Medium of Cultural Endurance: A Critic of Capitalism and Market Cultural. This study discusses the culture change in the postmodern era, and its effect on the world of art. Postmodern that emerged in paradigms and art creativity in Indonesia caused various effects, on the one hand can be seen as progress but on the other side become the cause of the decadence of cultural values.
\end{abstract}

Key words: postmodern, arts, culture.

\section{Pendahuluan}

Perkembangan kebudayaan baru yang mengglobal pada abad ini adalah suatu yang niscaya dan tidak dapat dibendung. Kondisi ini lahir sebagai akibat dari pesatnya kemajuan ekonomi, teknologi dan informasi dunia, dan yang tidak dapat dihindari pula pengaruhnya pada produksi seni, sebagaimana yang dikatakan Piliang, bahwa abad ke-21 telah membuka cakrawala baru dalam dunia estetik, sebagai akibat globalisasi ekonomi dan informasi yang melanda dunia (Piliang, 2004:261). Selanjutnya Piliang mengatakan, ruang kebudayaan semakin meluas, idiom-idiom kebudayaan semakin terfragmentasi dan bahasa kebudayaan semakin terdiferensi.

Kondisi ini juga memberi dampak pada dunia seni di Indonesia, yang dapat diihat dari perkembangan berbagai cabang kesenian yang bercorak kontemporer, postmodern, dengan pelabelan yang makin majemuk. Pergeseran bentuk dan estetika karya-karya seni yang dilahirkan, sebagai respons para seniman terhadap zaman sebagai new cultural intermediaries (perantara budaya baru) (Boerdieu, 1984). Budaya baru itu dengan cepat mensirkulasi informasi di antara bidang budaya yang sebelumnya tertutup rapat, serta pemunculan saluran-saluran komunikasi baru dalam kondisi persaingan yang sangat intensif (Crane, 1987 dalam Featherstone 2005:23).
Sejarah petumbuhan seni mempunyai kurun waktu yang panjang diawali dengan periode klasik, mimesis, abad pertengahan sampaiera post modern. Proses kreatif dari seniman dalam mencipta karya seni akan selalu mewakili semangat zamannya. Ada perbedaan yang mencolok dalam proses kreatif maupun dalam pandangan dan penilaian terhadap karya seni. Dalam proses kreatif, pada era yang serba teknologi ini seniman dimanjakan oleh berbagai kemudahan teknis. Pemanfaatan teknologi digital (video art, foto digital) memberi peluang kebebasan mencipta yang tanpa batas seperti munculnya lukisan virtual.

Bila kita coba membanding karya-karya yang dilahirkan seniman masa kini dengan para seniman pendahulunya, dapat dilihat perbedaan yang besar. Bila pada zaman lampau seniman bekerja secara manual, sekarang sudah dimudahkan oleh kemajuan teknologi. Seiring kemajuan zaman ini dimungkinkan juga terjadinya perbagai pergeseran ideologi dan cara pandang terhadap kebudayaan tentunya. Ihab Hassan (2002) menjelaskan itu dengan melihat adanya dikotomi antara apa yang dikatakannya sebagai kebudayaan modern dan postmodern. Menurut Hassan, kebudayaan modern ditandai dengan berkiblatnya pada narasi besar, adanya pemusatan, phalocentrisme, logosentrisme, mempunyai akar kedalaman, mempunyai tujuan yang jelas, terseleksi sehing-

* Alamat korespondensi: Jln. Suryodiningratan No. 8 Yogyakarta 55143, Tlp. 0274-419791, e-mail: admisi@pascaisi.com 
ga dikenal adanya budaya tinggi dan budaya rendah, menampilkan objek yang utuh (karya jadi) dan mengutamakan keaslian. Sedangkan budaya posmodernisme menjadi kebalikannya; mengakui narasi kecil, keterpecahan, androgini, antilogos, bersifat permukaan, merupakan permainan, kombinasi, happening, dan eklektik (menggabungkan berbagai perbedaan),

Kemajuan peradaban termasuk teknologi menghilangkan dikotomi wacana budaya tinggi dan budaya rendah. Kesenian tidak lagi semata menjadi budaya adiluhung dan memusat pada satu tempat saja (di zaman modern Taman Ismail Marzuki menjadi Mekkahnya seniman), hari ini seni sudah menyebar kemana-mana dalam bentuk komunitas-komunitas dan kelompok kecil yang membangun ruangnya sendiri-sendiri. Keadaan ini mengubah cara pandang, visi dan misi seniman dalam proses kreatifnya.

Pertumbuhan teknologi yang menimbulkan cara pandang baru itu menggiring perkembangan seni ke arah industri budaya dan ini berimbas pada perubahan dari berbagai cabang seni (teater, tari, seni rupa dan musik) dan eksistensi para seniman pelakunya.

\section{Perubahan Nilai dalam Proses Ber- kesenian}

Nilai budaya tumbuh sebagai bagian integral dari pandangan hidup masyarakat pelaku budaya, dari tempat sebuah tradisi budaya itu hidup. Ia menjadi kerangka yang secara ideologis berpengaruh pada sikap dan aktivitas seseorang dalam memandang hidup. Di lingkungan masyarakat kesenian, nilai budaya itu menjadi substansi yang mengilhami kreativitas seni. Akan tetapi, ketika perubahan peradaban menempatkan seniman sebagai bagian yang tidak terpisahkan dari gelombang kehidupan kapitalis, seniman masuk ke dalam suatu lingkar penandaan yang acak, yang oleh Piliang disebut sebagai dunia yang di dalamnya tidak ada kepastian posisi ideologis diri (2006:463).

Dalam dunia seni rupa misalnya, timbul kesulitan dalam mengidentifikasi karya, untuk menetukan kreatornya ataupun tradisi budaya yang diwakilinya, disebabkan munculnya karyakarya yang hampir mirip dengan pola yang sama, ketika seni telah menjadi industri dan diproduksi secara masal.. Media yang digunakan juga semakin beragam. Kita dapat melihat patung Asmat yang tidak terbuat dari kayu lagi, akan tetapi berbahan baku emas menggantung di telinga seseorang. Ketertarikan penikmat seni bersifat artificial, tanpa perlu memahami kedalaman makna yang dikandungnya. Akhirnya muncullah apa yang dinamakan simulacrum (tanda kosong), penanda yang tanpa makna. Lukisan Monalisa yang terkenal itu bisa saja termuat dalam sebuah kalender penghias dinding bersama dengan patung lilin Michael Jackson misalnya. Karya-karya itu bisa lahir dari belahan bumi mana saja dan sangat mudah diakses tanpa harus mengunjungi galeri atau museum sebagai kemudahan yang ditawarkan media.

Para seniman seolah kehilangan ciri khas. Di sisi lain kekuasaan pasar memungkinkan terjadinya trend dalam seni. Fenomena dalam dunia seni lukis misalnya, karya-karya yang muncul cenderung tergantung kepada musim dan minat pasar. Seniman tidak lagi berkarya sesuai dengan apa yang menjadi obsesi artistiknya, pelukisnya seolah dipaksa untuk mengikuti selera pasar, dan kekuatan nilai ditentukan oleh bagaimana kurator memberi tempat di tengah pemasaran, dengan mengapungkan nama pelukis tertentu. Dengan demikian tanda tangannya jauh lebih dihargai dibandingkan karyanya, yang dihasilkan tanpa kontemplasi akibat tuntutan produksi yang dikehendaki pasar.

Di sisi lain kemudian maraknya pertumbuhan karya-karya instalasi dan karya rupa yang mengandalkan teknologi (video art, digital) menciptakan ruang kreatif yang semakin tanpa batas. Sekatsekat antara berbagai cabang seni dibongkar, penikmat seni nyaris tidak lagi bisa membedakan antara pameran seni dengan seni pertunjukan, semuanya sudah membaur. Karya-karya instalasi ini mampu menembus ruang dan waktu, sangat imajinatif menawarkan ruang tafsir yang bebas terhadap penikmatnya. Akan tatapi seni Instalasi hanya bersifat temporer, mungkinkah karya seni ini memudahkan kita menemukan substansi yang ingin disampaikan seniman, atau seniman tetap harus menjelaskan secara lisan maupun tertulis untuk menggiring pemahaman penonton, atau hanya akan menjadi seni citraan saja.

Berbeda dengan seniman perupa pada masa lalu dan hanya beberapa seniman mutakhir, ada kekuatan artistik yang dimiliki masing-masing 
seniman, sehingga mereka punya ciri khas. Dalam karya-karya mereka dapat ditemukan ideologi penciptanya yang terpancar dari hasil karya mereka. Sebutlah beberapa nama seniman besar seperti, Affandi, Nashar, S.Sudjojono, Wakidi, Joko Pekik sampai pada perupa mutakhir Tisna Sanjaya misalnya. Kita bisa membaca karya mereka dari karakter dan nuansa yang tercipta.

Ini hanya sebagai pembanding bagi senimanseniman perupa sekarang, mereka juga seniman yang produktif dan melahirkan karya-karya yang bagus, bahkan kaya-karya merekapun lebih hebat dari seniman masa lalu (harganya sudah mencapai Milyaran). Masalahnya ada kondisi yang sudah berubah yakni kondisi lingkungan dan pertumbuhan dari kebudayaan itu sendiri. Perkembangan teknologi mesin serta komputerisasi yang semakin canggih memperluas ruang ekspresi estetis seniman. Kalau pada masa lalu para seniman melahirkan karya dari media yang terbatas sekarang justru sebaliknya media yang dipakai sangat banyak dan seolah tidak berbatas. Disisi lain kondisi ini tentu memberi dampak baik pada perkembangan seni, dengan semakin mudahnya informasi dan penyebaran karya ke berbagai pelosok dunia. Karya dan para senimanya dengan cepat terkenal. Kesenian tidak lagi memusat pada satu tempat saja tapi sudah menyebar ke berbagai pelosok dan bermunculan kantong-kantong seni baru (seperti maraknya pertumbuhan galeri seni).

Lalu bagaimana dengan ideologi yang dianut seniman sebagai pertanggung jawaban moral bagi pertumbuhan kultural bangsa ini. Adakah sama dengan seniman pada masa lalu atau sudah tergerus oleh ideologi pasar, kapitalisasi seni. Kapitalisasi seni berorientasi pasar dan hanya memerlukan mesin untuk memenuhi kebutuhan pasar. Kwalitas menjadi relatif, mencipta menjadi persoalan teknis. Tidak diperlukan lagi perenungan, tak perlu lagi filsafat, budaya rendah dan budaya tinggi sudah menjadi masa lalu, seniman dan tukang sudah semakin sulit dibedakan. Lalu dimanakah posisi seniman hari ini, ataukah posisi seni dan non seni tidak perlu lagi menjadi perdebatan (menjawab pernyataan Mikke Susanto dalam membongkar Seni Rupa).

Isu kapitalisasi seni tidak saja merambah dunia seni rupa, melainkan juga masuk pada wilayah cabang seni lainya seperti dunia musik misalnya.
Pesatnya perkembangan media merupakan lahan yang bagus untuk dunia musik, apalagi yang berkaitan dengan industri musik. Di Indonesia kenyataan ini dapat kita lihat dari maraknya kehadiran kelompok-kelompok musik yang mengusung aliran pop alternatif. Sebutlah Ungu, Peter Pan, Raja, Coklat (hanya itu yang terapresiasi ) mereka nyaris tiap hari menghiasi layar kaca menjadi panutan bagi generasi muda. Sangat jarang terlihat musik-musik yang adiluhung kecuali sesekali ada di pergelarkan secara ekslusif (di gedung pertunjukan) dinikmati segelintir orang,

Seni pra-modern memiliki hubungan organis dengan masyarakat yang mengekspresikan bentuk alami dari produksi seni tersebut secara ritual dan hubungan sosialnya (Turner,2006:227) sementara media massa dan budaya industri melahirkan produk massal yang dinikmati oleh seluruh lapisan elemen masyarakat secara massif. Kondisi ini tentu saja sangat berpengaruh terhadap pertumbuhan kebudayaan. Kita tidak lagi mendengar nama Slamet Abdul Syukur, Ben Pasaribu, Sapto Raharjo dan lain sebagainya. Industri budaya memberi peluang besar terhadap perkembangan industri musik. Pada saat ini menikmati musik tidak diperlukan lagi ruang khusus, kita sudah dimanjakan oleh tekhnologi. Musik-musik klasik tidak lagi menjadi barang mahal, semuanya dapat dicetak dalam bentuk kepingan CD dan di copikan dalam Hard Disk computer maupun flash disk dalam bentuk MP3 dan MP4 yang sedang digandrungi segala lapisan. Ruang tanpa sekat pemaknaan jadi kabur, aktivitas penikmatan lebih cenderung sekedar pemuasan hasrat. Kualitas tidak lagi ditentukan oleh para ahli tetapi diambil alih oleh massa (fenomena SMS pada festival musik di media)

Tanpa pengecualian, seni tari juga sudah kena imbasnya. Dunia tari sudah merambah masuk ke wilayah budaya industri. Tampil di media-media massa merupakan pilihan yang lebih menggiurkan dengan honorarium yang menjanjikan. Hedonisme dan glamour merupakan mimpi yang ditawarkan, yang menyeret pelaku seni tari pada realitas semu (Simulacrum).

Seni tari adalah salah satu cabang yang paling cepat beradaptasi dengan perkembangan budaya massa. Tari identik dengan dunia glamour, menyebabkan bidang ini menjadi pilihan banyak 
anak muda untuk menyalurkan energi kreatif mereka. Apalagi pilihan menggeluti dunia tari ini terbuka peluang untuk bisnis hiburan.

Pilihan untuk menngeluti tari klasik atau yang bermuatan seni dan budaya tidak lagi terlalu diminati. Untuk proses garapan sebuah karya saja berkemungkinan saat ini para koreografer kesulitan untuk menemukan penari yang berkualitas. Kondisi ini dipicu oleh pilihan para penari yang lebih realistis dan pragmatis, cenderung menjadi penari latar dari artis terkenal.

Padahal apabila lebih dicermati dan direnungkan bersama Indonesia sudah mempunyai seni tari tradisional di masing masing suku, yang merupakan budaya asli Indonesia. Masing-masing daerah memiliki seni tari tradisional, yang menjadi salah satu kekayaan khasanah kebudayaan Indonesia. Berbeda dengan seni rupa, musik (pengecualian pada beberapa jenis alat musik tradisi) dan teater modern yang merupakan produk impor (Barat), yang berjarak dengan garis sejarah kebudayaan tradisi Indonesia. Untuk lebih jelasnya kaitan teater dengan pertumbuhan kebudayaan di Indonesia ada baiknya selintas dibicarakan sejarahnya.

Pertumbuhan teater di Indonesia sudah dimulai sejak zaman kolonial Belanda, Teater modern Indonesia berkembang di kota-kota dagang dan pusat-pusat pemerintahan di zaman Belanda (Soemardjo,1992:15) akan tetapi jauh sebelumnya juga sudah berkembang di Indonesia berbagai jenis teater rakyat yang kita kenal sebagai teater tradisional. Setiap wilayah budaya mempunyai teater tradisional, yang spesifik dan khas seperti, Kentrung, Pantun Sunda, Bakaba, Cepung Sinrilili, Wayang dan lain sebagainya. Boen S. Oemarjati membagi pertumbuhan teater modern dalam beberapa periodisasi yakni, periodisasi kebangkitan, periode pembangunan, periode 1950-1963 (Boen S Oemarjati dalam Soemardjo, 1992:101) sementara Jakob Soemardjo membaginya menjadi empat periodisasi.

Masa perintisan teater modern ditandai dengan Komedi Bangsawan, Komedi Stambul danTeater Opera. Periodisasi selanjutnya merupakan kebangkitan teater modern yang ditandai dengan kehadiran berbagai kelompok seperti, Teater Miss Riboet,s Orion, Teater Dardanela Opera. Kemunculan kelompok ini merupakan awal terbentuknya pertumbuhan teater modern
Indonesia. Masa perkembangan selanjutnya adalah masa perkembangan teater modern yang ditandai dengan, teater zaman Jepang, teater tahun 50-an, teater tahun 60-an, dan selajutnya Jakob Soemardjo menamakan dengan periode mutakhir yakni perkembangan teater tahun 1970-1980.

Pendapat Jakob Soemardjo mengenai periode mutakhir tentu saja juga mengalami pergeseran, teater mutakhir di Indonesia masa kini adalah teater abad 21. Ditandai dengan persanggamaan dunia teater dengan tekhnologi industri, budaya massa dan kapitalisme global. Lalu kolaborasi ini melahirkan produksi teater dengan pelabelan kontemporer, postmodern, futuristic, circus teater, teater tubuh dan semuanya menghadirkan citraan dari bentuk- bentuk seni baru. Seni teater juga bermetamorfosis menjelajah dalam ruang tanpa sekat menyelusup dalam pertumbuhan kebudayaan yang semakin plural dapat menciptakan pula kebebasan penonton dimanamana. Tidak diperlukan lagi sebuah tafsir tunggal dalam menikmati seni teater, semua penonton boleh punya tafsir sendiri dari apa yang dapat ditangkap.

Pluralisme pikiran dengan pencirian menghargai keberagaman dan perbedaan memerangkap proses karya seni ke dalam bentuk yang hanya menghadirkan citraan. Karya seni kehilangan makna dan substansinya. Piliang melihat, realitas citraan ini membentuk abad ke- 20 sebagai abad citraan, yang mencapai kulminasi pada riuh rendah citraan elektronik (televisi, video clip, internet) serta sorak sorai idiom-idiom estetik postmodern (Pastische, kisch, parody, camp, perverse, skizofrenia). Kecenderungan ini akan terus berlanjut pada abad 21, namun tentunya dalam dimensi yang berbeda (Piliang,2004:263).

Teknologi industri memberi dampak yang signifikan terhadap perkembangan seni teater di Indonesia. Penempatan teknologi yang tidak tepat menyeret seni kita menjadi seni yang latah. Teknologiakan menjadi aktor utama, elemen lainya akan menjadi figuran. Kekhawatiran terjadinya dehumanisasi dalam seni dikemukakan oleh beberapa budayawan. Dalam bukunya Aesthetic Theory (1986), Adorno mengatakan bahwa:

Manusia telah dibodohi oleh budaya industri dan rasa lapar terhadap komoditas-komoditasnya, massa mendapati diri mereka 
berada di sisi seni yang memang begitulah keadaanya. Dalam pada itu, mereka berada dalam posisi mencerap ketidak tepatan. Kebohongan proses kehidupan yang dialami masyarakat lebih telanjang ketimbang yang dialami mereka yang masih ingat seharusnya untuk apa karya seni digunakan.....Hal ini akan sangat kentara di zaman kelebihan produksi sekarang ini, dimana aspek material dari nilai guna komoditas menjadi hilang; dimana konsumsi menjadi begitu dinikmati demi kebanggaan dan hasrat untuk selalu berada di atas; dimana karakter komoditas dari hal-hal yang biasa dikonsumsi sepertinya juga menghilang-inilah parodi ilusi estetik (Adorno, 1986:84).

Adorno mengisyaratkan bahwa manusia tidak lagi menjadi subjek bagi lingkungannya, terjadi dehumanisasi dimana manusia dikendalikan oleh pasar yang muncul dari proses kapitalisasi. Dengan demikian sangat tidak adil bila kemajuan teknologi dan budaya industri dianggap sebagai penyebab terjadinya erosi pemikiran dan pertumbuhan dunia kesenian masa kini. Bagaimanapun kemajuan peradaban tetap memberikan sumbangan positif terhadap perkembangan zaman. Persoalannya adalah bagaimana upaya membangun kesadaran kultural, dengan mempertahankan dan terus menghidupi kekayaan budaya yang sudah dimiliki.

Indonesia adalah negeri yang sangat kaya dengan khasanah budayanya, seperti halnya negeri-negeri timur lainnya. Pada era tahun19701980-an seniman teater Indonesia bersepakat untuk menengok tradisi setelah sekian lama mereka berkutat dengan teater modern Barat. Tentu kondisi ini dilakukan bukan tanpa alasan. Modernisme pada waktu itu ternyata juga dianggap sebagai ancaman (yang terjadi pertumbuhan yang tidak seimbang) terhadap pertumbuhan budaya lokal. Lalu dengan kesepakatan bersama para seniman teater berkarya dengan memanfaatkan idiom tradisi. Masing-masing seniman membawa tradisi dimana mereka tumbuh dan dilahirkan. Putu Wijaya dengan latar belakang Balinya, Wisran Hadi mengolah randai dari Minangkabau, Arifin C Noer dengan latar belakang Cirebon sebutlah beberapa seniman lainya seperti Aspar Paturusi (Makassar), Suyatna Anirun (Bandung), Nano Rintiarno yang lebih konsern pada budaya
Tionghoa dan teater rakyat Betawi, dan WS Rendra dengan eksplorasi tradisi budaya Jawa. Mereka hadir sebagai pendekar-teater di Indonesia.

Lantas apa yang membuat mereka hadir dan menjadi tonggak bagi pertumbuhan teater di Indonesia. Kondisi zamankah atau cara perprosesnya yang berbeda. Merujuk pada kondisi zaman pada saat itu teknologi belum begitu maju jika dibanding dengan kondisi sekarang. Mereka tidak dimanjakan oleh apa yang dinamakan indusri budaya. Intensitas dan pergumulan dengan tradisi yang menjadikan mereka besar. Tradisi dijadikan sumber inspirasi bagi pertumbuhan budaya ke depan serta menggali substansi tradisi dan tidak melakukan negasi terhadapnya. Ada kesadaran untuk membangun identitas seni atas kekuatan budaya sendiri.

Demikian juga dengan dunia kesusastraan kita, juga mengalami fenomena pergeseran yang tak dapat dihindari. Pada karya sastra masa lalu hasil tulisan berupa novel, cerpen dan puisi merupakan sebuah respon dari masalah sosial dan cultural, dari proses kajian dan perenungan yang dalam. Saat ini, novelis dan cerpenis yang menghasilkan karya bermutu bisa dihitung dengan jari. Bermutu dan tidaknya karya yang dihadirkan ditentukan oleh para kritikus ahli sehingga menghasilkan karya yang selektif. Akan tetapi sekarang sistem itu tidak berlaku lagi. Saat ini siapa saja bisa menulis, hasil tulisan tidak lagi ditentukan oleh segelintir orang, tetapi bisa ditentukan oleh pasar, komunitaskomunitas sendiri yang mampu membuat publikasi dan punya dana untuk launching buku.

Kebebasan ekspresi dan kebebasan melontarkan pikiran serta menghargai keberagaman merupakan ciri dari bentuk-bentuk posmodern sehingga kita sulit menentukan sebuah kebenaran karena masing-masingnya punya sisi itu. Karya-karya sastra mutakhir banyak mengekspos hal yang semula dipandang tabu (hubungan laki-laki dan perempuan, sesama jenis, alat kelamin dsb). Brian Mchale (1987) dalam bukunya Posmodern Fiction menyebut peralihan itu sebagai berlakunya dominan, dari budaya yang epistemologis ke kebudayaan yang dominan ontologis. Fiksi posmodern yang berkembang hari ini adalah cerita tentang kemanusiaan yang ditampilkan apa adanya, tanpa hakekat kemanusiaan, mengangkat lapis terendah pengalaman manusia. 
Sebagai dampak dari teknologi industri dan industri budaya ini terbentuknya budaya pasar. Karya seni tidak lagi otonom menjadi milik seniman tetapi sudah di intervensi oleh pasar. Dalam kondisi seperti itu, ilmu manajemen menjadi berperan penting. Ilmu manajemen semakin berkembang seiring dengan pertumbuhan dan kebutuhan akan pemasaran kesenian yang semakin meningkat.

Kehadiran manajemen dalam dunia seni seakan menjadi mutlak sebagaiman layaknya sebuah perusaahan industri. Seni pertunjukan memerlukan para manejer untuk pemasaran dan promosi. Perupa bergantung pada para kurator untuk pemasaran karya. Dengan ilmu manajemen dibangun sebuah kerajaan kesenian yang mampu membinajaringan antar kultural. Maju mundurnya kesenian tergantung pada tim manajemen sebagai pengelola. Kecanggihan tekhnologipun sangat mendukung bagi sebuah proses manajemen seni dengan kemampuan mendatangkan lembagalembaga donor dari pihak asing dalam bentuk NGO dam lembaga Founding.

Kondisi ini secara finansial tentu sangat menguntungkan. Bisa memberi kehidupan pada kelompok-kelompok seni yang biasanya selama ini kesulitan dalam urusan pendanaan (yang paling sering adalah seni teater). Akan tetapi mungkinkah lembaga lembaga tersebut memberikan bantuan dengan cuma-cuma saja. Hal ini perlu kita renungkan bersama, bukan tidak mungkin ini merupakan sebuah proyek besar dari kaum orientalis melalui celah seni dan budaya, kita tidak lagi membangun budaya dengan kehendak sendiri melainkan sesuai dengan keinginan lembaga pemberi donor, Fenomena ini sebelumnya lebih kelihatan pada ranah politik dan sosial dengan menjamurnya LSM-LSM luar negeri di Indonesia. Keabsahanya tentunya perlu penelitian lagi.

\section{Tradisi sebagai Alternatif Ketahanan Budaya}

Pertanyaannya, dimanakah posisi kitasekarang? Berbagai kemajuan menjadi sebuah realitas zaman yang tidak bisa ditolak. Walaupun demikian membangun kesadaran untuk mempertahan kan nilai-nilai budaya merupakan hal yang perlu dipertimbangkan. Pada masa awal kemerdekaan misalnya, seperti yang dikatakan Piliang bahwa pada masa itu perlunya membangun identitas diri, budaya dan karakter bangsa menjadi sangat penting di dalam kondisi bangsa-bangsa yang baru melepaskan dirinya dari cengkeraman kolonial. Akan tetapi, di penghujung abad ke-20 ini, konsep bangsa-bangsa menjadi inti dari pembentukan identitas budaya justru banyak diserang. Yang berkembang kini adalah semangat pluralisme dan sinkretisme budaya (Piliang,2004:283). Serangan yang berkemungkinan timbul tidak atas dasar kesadaran tentang pentingnya ranah kebebasan mencipta sebagai otoritas yang dimiliki seniman, akan tetapi lahir dari gelombang suara globalisasi yang tidak disadari bagaimana dampaknya di masa datang. Sikap pragmatis yang hanya memikirkan apa yang dapat diambil dari kondisi hari ini dan untuk kini memunculkan pula komunitas baru.

Komunitas baru itu terbentuk tidak lagi berdasarkan atas kesadaran kesamaan kultural, tapi lebih mengedepankan kesamaan visi secara personal.Akhirnya bermunculan semangat primordial dalam arti yang sempit yakni membangun kesamaan kepentingan. Tanpa disadari sebetulnya ini merupakan sebuah proses penyeragaman yang boleh jadi diinginkan oleh kaum kapitalis dalam proses penguasaan dan memperkuat posisi sebagai polisi dunia bahkan di wilayah kebudayaan. Penggerusan nilai-nilai budaya dan menggantinya dengan corak kapitalis yang serba materiaslistis sebagai tujuan akhir yang dapat berdampak kepada hilangnya identitas, budaya mengambang tanpa grafitasi dalam orbit budaya dunia yang tanpa akar.

Keseragaman yang ditimbulkan budaya kapitalis telah masuk ke dalam bilik-bilik pribadi kita, tanpa disadari. Mall telah menggantikan pasar-pasar tradisional yang menjadi bagian dari pencirian keanekaragaman budaya bangsa. Kita tidak lagi dapat membedakan model bangunan maupun apa yang ada di dalamnya, seperti mall-mall, super market, apartemen yang ada di Amerika, Singapura, dengan corak bangunan yang ada di Jakarta. Malahan juga corak seperti ini sudah sampai ke pelosok yang terpencil di pulau Sumatra. Semua model bangunan tersebut mempunyai ciri yang sama dengan bangun ruang kaku cenderung berbentuk segi empat (hutan beton ).

Membangun kesadaran akan perlunya kembali kepada nilai-nilai budaya merupakan pilihan 
bijak sebagai upaya revitalisasi budaya tradisional. Untuk mencapai kedalaman substansi dari masalah-masalah kebudayaan ini maka diperlukan pendekatan secara holistik. Dengan demikian peran serta dunia keilmuan menjadi penting demi terciptanya sebuah bentuk budaya unggul yang mampu menjelaskan identitas bangsa untuk membangkitkan rasa kesadaran budaya, tidak hanya dalam konteks narasi kecil saja, tapi juga mempunyai kemampuan untuk membangun sebuah narasi besar dalam konteks kultural yang mengglobal.

Melirik kembali seni tradisi dalam menghadirkan sebuah pertunjukan modern bukan merupakan hal yang baru. Hal ini sudah dilakukan juga oleh para seniman teater di era yang lalu. Akan tetapi pada kondisi sekarang tradisi perlu menjadi pertimbangan lagi, tentu saja dengan pola dan pendekatan yang disesuaikan dengan konteks hari ini. Di tengah serbuan globalisasi, menengok kembali pada tradisi bukan hal yang sederhana, diperlukan kearifan dan pendekatan keilmuan. Meskipun pada kenyataannya, dunia postmodern tidaklah terpisah dari kepercayaan tradisional. Posmodern yang timbul di satu sisi dari kerontangnya kapitalisme menimbulkan kehidupan yang kering, yang kemudian pecah. Narasi besar yang pecah membentuk narasi kecil yang menyebar di satu sisi menemukan bentuknya dalam media dan hiburan, sebagian sisi yang lain mengalihkan pandangan pada simbol-simbol kultural, mendekonstruksi dan menciptakan pemahaman kembali (Piliang,2006:405).

Dunia mistik, mitos atau suguhan yang berbungkus budaya tidak pernah meninggalkan atau ditinggalkan oleh manusia. Pada kenyataanya pada tayangan media hari ini banyak sekali halhal yang berbau klenik diiklankan oleh media (SMS ramalan nasib, jodoh, dan peruntungan) ini merupakan bentuk tafsiran baru dari budaya lokal yang sudah dipengaruhi budaya industri dengan kemasan yang berbeda tentunya. Akan tetapi kembali menengok tradisi kepercayaan lama dalam hal ini tetap berasal dari sisi pragmatis, menggunakan kepercayaan tradisi sebagai jalan menentukan arah hidup secara instant. Pada dasarnya kepentingannya masih berkaitan dengan keuntungan praktis, bukan menggalian tradisi bagi kepentingan ketahanan budaya. Demikian juga dalam dunia medis, pengetahuan pengobatan yang sebelumnya selalu mengutamakan ilmu kedokteran modern, obat-obatan modern yang sudah dikemas dalam teknologi tinggi sekarang beralih pada pengobatan alternatif yang mengutamakan doa dan ramuan tradisional, setelah bahaya kimiawi menjadi momok baru bagi kehidupan mereka.

Berbeda dengan pandangan posmodern yang oleh Ihab Hassan disebut sebagai bagian dari modernisme, yang melihat segala sesuatu secara pragmatis, bagi masyarakat tradisi, kebudayaan mereka pandang sebagai inisiasi dari pandangan hidup yang sublim sebagai membentuk gerak keseharian mereka. Dan pandangan tradisi itu belum sepenuhnya pupus dari mentalitas masyarakat, karena bila dikaitkan dengan kekuasaan yang membentuknya, Orde Baru yang berusaha membentuk keseragaman pandangan telah gagal. Ia selalu berada dalam tegangan kultural antara keberagaman budaya dengan kehendak untuk menyatukan pandangan. Dengan demikian pada dasarnya pondasi kultural yang menjadi basis ketahanan budaya itu masih akan mampu mengakomodasi nilai hakiki kebudayaan, meskipun tidak dapat dipungkiri, kapitalisme dan pasar menggerusnya dengan cukup keras.

Upaya membangkitkan kembali kesadaran kultural dengan menjadikan tradisi sebagai bahan dasar dalam upaya penempatan kembali seni tradisi menjadi local genius, menjadi kekuatan ditengah serbuan budaya global. Local genius membangkitkan kesadaran kultural untuk lebih arif dan tidak terjebak hal yang palsu dan parodi. Kesadaran ini dibangkitkan melalui dunia kesenian yang dapat dipandang sebagai dunia yang tetap menjadi penjaga kesadaran kultural, dan ini merupakan sebuah pilihan.

Pada masanya, Goenawan Mohammad menyatakan dirinya sebagai penyair yang menjadi si Malin Kundang bagi kebudayaannya. Pernyataan ini mengindikasikan terjadinya pencarian kreatif yang dilakukan dengan sadar dengan meninggalkan induk kebudayaannya, ia berkiblat kepada kebudayaan Barat. Hal itu bisa dipahami dengan latar kultur, tradisi berfikir dan proses pembelajaran yang terbentuk bersama pemikiran-pemikiran Yunani yang menjadi induk kebudayaan barat yang dianutnya. Baginya pun itu sebuah pilihan. Akan tetapi tidak semua seniman punya proses yang sama, oleh karena itu adalah naï untuk 
memandang kebudayaan dalam perspektif yang sama pula.

\section{Peran Lembaga Kebudayaan dan Lembaga Pendidikan Kesenian}

Disamping seniman yang berproses secara otodidak, sebagian besar seniman Indonesia hari ini merupakan produk dari lembaga-lembaga pendidikan kesenian dan kebudayaan yang mulai tumbuh di negeri ini sejak awal tahun 1960-an. Walaupun tidak dapat diingkari bahwa di dalam sistem pendidikan itu sendiri terjadi transfer nilai dari kebudayaan scholar Barat, akan tetapi ia tetap bersentuhan secara intens dengan tradisi budaya setempat.

Dalam memandang sumbangan budaya barat itu, lembaga pendidikan kesenian seyogyanya menjadi lembaga yang secara arif dapat memanfaatkan perkembangan pengetahuan Barat yang lebih metodologis secara selektif, dengan tetap berpegang pada pandangan kultural. Barat dapat membantu dengan kemajuan teknologinya dan metode pengetahuannya yang dapat digunakan sementara waktu, menjelang ditemukannya metode yang mengakar pada budaya sendiri. Untuk itu, diperlukan pemikiran kreatif dan pergulatan terus menerus dalam menemukan formulasi metodologis yang paling sesuai.

Ilmuan seni dan budayawan semestinya tidak hanya mengadopsi teori-teori Barat dan memaksakan atau setidaknya mencocokkan dengan realitas yang ada di lingkungannya. Kurikulum pendidikan dengan dasar pijak dan tujuan yang jelas dalam hal ini sangat dibutuhkan. Sebaliknya perlakuan terhadap tradisi pun harus tetap kritis. Bila tidak tradisi hanya akan menjadi artefak, bukan menjadi kebudayaan yang hidup. Selamanya pandangan tentang garis imajinasi yang membelah dunia; Barat yang maju dan berkembang dan Timur yang tinggal puing dan semakin tenggelam, akan tetap bertahan demikian. Karena disadari atau tidak saat ini, keberpihakan jaringan bantuan Internasional kepada masyarakat dan kebudayaan di negara berkembang melalui berbagai fundrising tetaplah berkaitan erat dengan kapitalisme. Mereka memandang orang-orang yang dibantunya sebagai kaum tertindas yang membutuhkan uluran tangan dalam posisi yang berbeda dengan mereka, sebagai liyan.
Lembaga-lembaga kebudayaan pun mempunyai peran yang besar dalam ketahanan budaya. Di dalam lembaga seperti Taman Budaya dan Dewan Kesenian misalnya, diperlukan sumberdaya manusia yang kritis dan berpandangan jauh ke depan. Bila lembaga-lembaga itu masih "mengeluselus" seni tradisi sebagai barang peninggalan masa lampau yang patut dilestarikan, mereka hanya akan berperan sebagai agen promosi benda-benda purbakala, sementara kebudayaan sekali lagi adalah sesuatu yang hidup. Tradisi akan bermakna apabila ada seniman kreatif di dalamnya. Seniman yang tidak hanya melihat kebudayaan secara artifisial, akan tetapi menggali nilai-nilai yang substansial.

\section{Penutup}

Setiap kebudayaan mempunyai kearifan dan nilai yang harus ditarnsformasi. Dalam menghadapi kekuatan neo-liberal yang tanpa disadari menggiring manusia masuk ke dalam pasar global dengan Amerikanisasi budaya, penting artinya menempatkan posisi melalui ketahanan tradisi. Peran seniman yang di satu sisi dapat menjadi agen perubahan, di sisi lain berperan besar memperjuangkan transformasi nilai budaya bangsa, dalam usaha itu penting artinya. Akan tetapi ia tak mungkin bekerja sendiri, diperlukan Political Will dari lembaga terkait. Oleh karena itu lembaga-lembaga budaya perlu mengatur barisan dengan menyusun agenda kegiatan yang jelas dengan prospek ke depan, karena ketahanan budaya adalah asset dan investasi yang hasilnya dapat dinikmati dalam jangka panjang.

\section{Kepustakaan}

Adorno,Theodor. 1986. Aesthetic Theory. London \& New York: Routledge \& Kegan Paul.

Dahana, Radhar Panca. 2000. Homo Teatericus. Magelang: Indonesia Tera.

Ediwar. 2003. "Tradisi Lisan "Baluambek" dalam Upacara "Alek Pauleh Tinggi" di Pariaman Sumatra Barat". Jurnal ATL. Jakarta: Penerbit Asosiasi Tradisi Lisan.

Featherstone, Mike. 2005. Postmodernisme dan Budaya Konsumerisme. Yogyakarta : Penerbit Pustaka Pelajar Offset.

Koentjaraningrat. 1987. Sejarah Teori Antropologi. Jakarta: UI Press. 
Marinis, Marco De. 1993. The Semiotics of Performance. Bloomington and Indiana Polis: Indiana University Press.

Piliang, Yasraf Amir. 2006. Dunia yang Dilipat Tamasya Melampaui Batas-Batas Kebudayaan. Yogyakarta: Penerbit Jalasutra.

Saini KM, 1996. Peristiwa Teater, Bandung: Penerbit ITB.
Sumardjo Jacob, 1992. Perkembangan Teater Modern dan Sastra Drama Indonesia. Bandung: Penerbit PT Citra Aditya Bakti.

Susanto, Mike. 2003. Membongkar Seni Rupa, Yogyakarta: Penerbit Buku Baik dan Penerbit Jendela.

Turner, Bryan S. 2006. Runtuhnya Universalitas Sosiologi Barat. Yogyakarta : Penerbit AR_RUZZ MEDIA. 